\title{
TOTAL FACTOR PRODUCTIVITY OF MANUFACTURING SECTOR IN INDIA: A REGIONAL ANALYSIS FOR THE STATE OF HARYANA
}

\author{
Shallu Sehgal* and Suparn Sharma**
}

\begin{abstract}
Using pooled data for the period of 1981-82 to 2007-08 for different categories of organized sector's manufacturing industries for the sample state of Haryana, the present undertaking seeks to analyze the inter-temporal and inter-industry comparison of total factor productivity (TFP) measured by Malmquist productivity index (MPI), which is an application of DEA to panel data to calculate the indices of TFP change, technology change, efficiency change. The general development pattern observed by the Haryana is definitely not a healthy sign of structural change in the economy. The analysis of the discussion reflects that while the tertiary sectors have maintained its lion's share in GDP of India and Haryana as well, the declining trend in the share of primary sector and more or less stable contribution of the secondary sector is noticeable. The study reveals that technical efficiency change is the key driver of TFPG in the manufacturing sector of Haryana during pre reforms period, however, the picture has turned around during the post reforms period. A positive impact of liberalization policy on technological advancement of the manufacturing sector of the state has been experienced. But, during the post reforms period the state has realized inefficiency in the utilization of resources in hand and it is really an alarming sign indicating that the incapability of manufacturing sector of the state in question to cope up with the technological advancement.
\end{abstract}

Keywords: total factor productivity, manufacturing sector, pooled data, state of Haryana, India

\section{INTRODUCTION}

Productivity growth is essential not only to increase output, but also to improve the competitiveness of an industry both in the domestic and international markets. The growth of an economy is governed by two distinct sources of growth that is, inputdriven and productivity-driven. The input-driven growth is achieved through the increase in factors of production which is certainly subjected to diminishing returns and is not sustainable in the long run as suggested by Young (1992); Krugman (1994). The productivity-driven growth is the growth in output that cannot be explained by the growth in total inputs. It is normally credited to the improvement in knowledge, organizational structure, human resources management, skills attainment, information technology and efficient use of factors of production. In more recent years equal

\footnotetext{
* Sehgal is Assistant Professor, Department of Economics, University of Jammu, Jammu.

** Dr. Sharma is Assistant Professor, School of Business Economics, College of Management, Shri Mata Vaishno Devi University, Katra 182320
} 
weight to productivity growth along with capital accumulation has been given, whether one took the structural outlook of the development, or the classical one, in oth the cases, productivity is critical to the outcome (Arora $\mathcal{E}$ Singh, 2008). The growth in productivity, which is also known as total factor productivity growth (TFPG), is the difference between the actual growth of output and the growth due to a composite of all factor inputs. Productivity isn't everything, but in long run it is almost everything (Krugman, 1990). Thus, in long run the only sustained manner to increase per capita gross domestic production (GDP) is by increasing the amount of output produced by a given quantity of inputs, that is raising total factor productivity (TFP). Productivity growth is accepted as a key characteristic of economic dynamism.

It becomes pertinent to analyze the productivity performance of the industrial sector which is facing stiff competition from outside world in the era of globalization and liberalization where the role of government is restricted. The present study is structured in way such a way where Section II endows with review of literature related with the present study; while Section III deals methodology used for the purpose of the study and this section contain information regarding database and variables used. Evaluation of the results is summarized and discussed in Section IV and to end with, the Section V comprises of conclusion and suggestions.

\section{LITERATURE REVIEW}

There are several studies on productivity growth in the Indian manufacturing sector but one could find that these estimates vary widely depending upon the methodology used and the period covered. One of the pioneer studies (researchers) in the field of productivity, Fare et al. (1994) analyzed the productivity growth of 17 OECD countries over the period of 1979 to 1988 using non parametric programming method and concluded that productivity growth of United States is slightly higher than average growth and this is due to technology progress. They also concluded that Japan's productivity growth is the highest in the sample with almost half due to efficiency change.

Among the post 1980 studies, the study of Ahluwalia (1991) is considered as a significant one. The main objective of the study was to calculate the growth rate of TFP in Indian manufacturing industries covering a period from 1964-65 to 1985-86. The study based on the Annual Survey of Industry (ASI) data, found a marked increase in the growth rate of TFP at 3.4 per cent per annum of Indian manufacturing. The estimates of translog production function using pooled cross-section and time series data also showed a marked improvement in the rate of TFP growth. She attributed this observed "turnaround" in productivity growth in Indian manufacturing in the 1980s to liberalization of economic policies. Misra (2006) focused on the impact of India's economic reforms on industrial structure and productivity. The discussion used the ASI data and covered both the two-digit and three-digit level of industries. The study has shown very low performance of Indian manufacturing sector and the reason for 
such a bad performance was the consequences of the type of policies being followed under reforms.

Leachman et al. (2005) used data from eight major automobile manufacturers and adopted a two stage model to study the performance of manufacturing units. They considered R\&D intensity (ratio of expenditure on R\&D and sales) as one of the explanatory variables, while determining the level of efficiency of manufactures and thus demonstrated that a strong R\&D commitment and capability to reduce production time. Jajri et al. (2006) in their attempt analyzed trend of technical efficiency, technological change and TFPG in the Malaysian manufacturing sector and concluded that during the period under study, TFPG increased and the major contribution for the growth is technical efficiency. The study by Manjappa and Majesha (2008) examined the TFPG and its components in ten manufacturing industries. He classified them into capital-intensive and labour-intensive industries (five in each segment) using annual time series data for the period of 1994 to 2004. The study applied MPI on panel data and concluded that the average TFPG in the capital-intensive industry segment grew moderately at 1.7 per cent per annum, whereas, in its counterpart, selected labourintensive industries have showed a productivity regress over the period of study.

Heshmati and Kumbhakar (2010) in their study used panel data on Chinese provinces and identified a number of key technology shifters and their effect on technical change and TFPG. Mahadevan $(2001,2002)$ used both stochastic frontier approach and DEA separately to calculate the TFPG of Malaysian manufacturing industries during 19811996. He used the same data set to make comparison between the two approaches and concluded that both methods demonstrated a decline of TFPG after 1990, increasing contribution of technology progress and declining contribution of technical efficiency change.

Joshi and Singh (2010) measured the TFP and identifies its sources through applying a non-parametric DEA-based MPI approach. Through this approach, the productivity growth was decomposed into technical efficiency change and technological change. Further, an attempt had also been made to study the variation in the productivity growth rates across location, scale-size and type of garments.

There are very few other studies as well which have estimated the productivity at regional level. Seth and Goldar (1989) have studied trends in industrial output in 12 states of India during the period 1960-61 to 1985-86. Confined to organized manufacturing sector, the growth rates in industrial output have been estimated for 3 sub periods using kinked exponential model. According to the study, after 1960s, all states experienced a decline in the rates of industrial growth measured in terms of net value added per capita in organized manufacturing (at 1970-71 prices) though the extent of deceleration varied from state to state. Further, Goldar and Veeramani (2005) studied the relationship of investment climate with the level of TFP for selected 
states of the country. Another attempt is made by Trivedi (2004) to interpret inter-state differences in productivity movements in organized manufacturing sector, in a larger perspective of employment and output trends. With the time span of 1980-81 to 200001 in case of 10 major states of India, the study empirically confirmed the existence of inter-state differences in productivity levels and growth rates. It points out that states, such as, Bihar and West Bengal are diverging away rather than converging to the growth rates of output of organized manufacturing sector at national level.

Kumar (2004) measured total factor productivity growth for industrial manufacturing sector of 15 major states of India for the period 1982-83 to 2000-01 using nonparametric linear programming approach. The analysis has also been done to measure the sources of TFPG and level of biasness in technical change. Findings of the study signified improvement in TFP. The study pointed out that regional differences in TFP persist in India, although the magnitude of variation has declined in the post reforms period. Moreover, it is also found that there is a tendency of convergence in terms of TFP growth rate among Indian states during the post reforms period and only the states that were technically efficient at the beginning of the reforms remain innovative. Norsworthy and Jang (1992) found mixed results for Indian manufacturing industries across the states. They found that Indian heavy industry exhibited a higher growth potential in terms of TFP.

Ray (1997) used a non parametric method of DEA to measure a Malmquist productivity index for manufacturing sector in the different states in India for the period 196984. The measured Malmquist productivity index is decomposed to separate the contribution of technical change, change in technical efficiency and change in scale efficiency. The analysis depicted that in most of the states productivity decline is due to technical regress. The regression results further suggest that it is the greater urbanization and higher capital-labour ratio that can promote productivity in India. As against this higher incidence of industrial disputes and preponderance of non production workers can hinder the productivity growth. Another study by Ray (2003) measured technical efficiency by using DEA approach and productivity by using Tornquist and Malmquist index for some of the Indian states. The estimated results show that annual rate of productivity growth by both the methods has been higher in the post reforms period than in the pre reforms period. However, some states like Assam, Himachal Pradesh and Orissa has witnessed productivity regress during post reforms period. Decomposition of Malmquist productivity index illustrated that improvement in technical efficiency as well as faster rates of technical progress contributed to the observed acceleration in the growth rate. A subsequent regression results confirmed that there is a tendency towards convergence in productivity growth rates across states.

There are many studies on productivity growth in Indian manufacturing sector but one could find that these estimates vary widely depending upon the methodology 
used and the period covered. As discussed in the above paragraphs, there are bountiful studies conducted so far to measure the productivity performance of Indian industry both at aggregate and disaggregate level (Ahulwalia, 1991; Goldar, 1986; Unel, 2003; Misra, 2006; Manjappa \& Majesha, 2008). On the other hand there are few studies that tried to analysis the inter-state variations with respect to productivity performance (Ray, 1997; Ray, 2002; Trivedi, 2004; Kumar, 2004; Goldar \&Veeramani, 2005). But the review of literature also wrap up that, there is serious dearth of studies where efforts have been made to study different dimensions of total factor productivity and its components growth and related issues at the regional and disaggregate level.

It becomes crucial to study the pattern and level of growth of productivity and efficiency of the manufacturing sector at the regional level for different states of the Indian union in particular as the Indian economy is about to complete two decades of economic reforms and this type of micro level study would prepare an empirical and true picture of the performance of the manufacturing sector at the regional level. On the similar lines, the present attempt seeks to analyze the intertemporal and inter-industry comparison of TFP of the organized manufacturing sector of Haryana by Malmquist productivity index (MPI) using non- parametric Data Envelopment Analysis. The growth of manufacturing sector in Haryana state is the need of the hour, as the agriculture growth appears to have already reached a plateau after enjoying a period of high growth in the wake of Green Revolution (Sharma, 2011). With the same commitment and passion an attempt has been made in the present endeavor to prepare in depth analysis of manufacturing sector of the state of Haryana, which is one of the emerging and important economies of the country.

\section{RESEARCH METHODOLOGY}

\section{Data Depiction and Dimensions of Variables}

The data on GDP and its components are extracted from Central Statistical Organization (CSO). CSO does the task of compiling the statistics for GDP for all the states and Union territories in India. The study used the series on GDP comprising for period from 1981-82 to 2007-08. As the data is available with different base series, for the purpose of the study the data for India and Haryana is converted into 1993-94 base by using splicing methodology, in order to get the time series data with a single base. For computing the MPI, the required two digit level data of manufacturing sector of Haryana in a balanced panel data format which have been culled out from the various issues of "Summary Results of Annual Survey of Industries". It is pertinent to mention here that since the present analysis of TFP in manufacturing sector of sample state of Haryana is confined to the period from 1981-82 to 2007-08(Period-I) and more in-depth analysis the pooled data has also been studied for two sub periods i.e. pre reforms (Period-II 1981-82 to 1991-92) and post reforms period (Period-III 1992-93 to 2007-08). 
As such the required data is available with different National Industrial Classifications (NIC). The NIC-1970 was followed to classify economic activities of the factories from ASI 1981-82 to ASI 1988-89. NIC- 1987 had been introduced and followed till 1997-98. NIC-1998 was then followed from ASI 1998-99 to ASI 2003-04. From 2004-05, the new series of classification, i.e., NIC-2004 has been introduced and the same has been used till ASI 2007-08. For the present study all the required time series data is prepared on the basis of NIC-87 by using the available two digit concordance tables. In the present study, only one output (gross value added at constant prices) and two inputs (gross fixed capital at constant prices and number of employees) model is considered. Following Jayadevan (1995) and Goldar (1986), the study preferred the use of gross value added as an index of output instead of net value added because the depreciation charges in Indian industries are known to be highly arbitrary fixed by the income tax authorities and seldom represent true/actual capital consumption. Using appropriate price deflators, all the nominal values have been deflated and the gross value added figures at constant prices (1993-94) have been utilized as an index of output. The study used the gross fixed capital stock as a measure of capital input. The standard practice of perpetual inventory method has been followed here to generate the series of gross fixed capital (GFC) stock at constant prices in the following way:

Step I: Following Goldar (1986) and Balkrishnan and Pushapgandan (1994) double the book value of fixed capital is taken as a measure of capital stock for the year 1993-94. It is obtained as:

$$
\mathrm{K}_{0}=2\left(B_{1981-82}\right)
$$

Step II: The gross real investment $\left(I_{t}\right)$ has been obtained by using following relationship:

$$
I_{t}=\frac{B_{t}-B_{t-1}+D_{t}}{P_{t}}
$$

where, $B_{t}=$ book value of fixed capital in the year $t ; D_{t}=$ value of depreciation of fixed assets in year $t$; and $P_{t}=$ price index for machinery and machine tools for year $t$.

Step III: After obtaining the estimates of fixed capital for benchmark year and gross real investment, the following equation has been used for the measurement of gross fixed capital series at 1981-82 prices:

$$
\mathrm{K}_{\mathrm{t}}=\mathrm{K}_{\mathrm{t}-1}+\mathrm{I}_{\mathrm{t}}-\delta \mathrm{K}_{\mathrm{t}-1}
$$

Where, $\mathrm{K}_{\mathrm{t}}=$ gross fixed capital by the end of year $\mathrm{t}$; $\mathrm{I}_{\mathrm{t}}$ =gross real investment in fixed capital during the year $\mathrm{t}$; and $\delta=$ annual rate of discard of capital. Following Unel 
(2003), the present study has taken annual rate of discarding of capital equals to 5 per cent.

The information of total person engaged provided by annual survey of industries consisting of both non-production and production workers, has been taken as a measure of labour input.

\section{Malmquist Productivity Index (MPI)}

The traditional approach to productivity measurement is partial factor productivity which is an indicator of the ratio of total output to a single input such as capital input but it ignores the contribution of other inputs. Thus, the concept of TFP is more appropriate in context of resource use productivity. The TFP is an index of output divided by an index of input bundle, and refers to the change in the productivity over time. The different approaches of TFP measurement are growth accounting approach, stochastic frontier analysis (SFA) and DEA based Malmquist productivity index (Joshi and Singh, 2010). The growth accounting approach requires the specification of a production function and makes unrealistic assumptions like constant returns to scale and perfect competition. It assumes that a firm operates on its production frontier, implying that it has no technical inefficiency. Thus, TFPG measured through this approach is due to technical change, not due to technical efficiency change (Mawson et al., 2003). In modern world, SFA and DEA based MPI have become popular approaches for estimation of TFP. In comparison with the SFA the DEA has important advantages such as; it does not require any functional form for the production function (Joshi and Singh, 2010). Grifell-Tatje Lovell (1996) suggested three main advantages of this approach. First, it does not require the profit maximization, or cost minimization, assumption. Second, it does not require information on the input and output prices. Finally, if the researcher has panel data, it allows the decomposition of productivity changes into two components the indices of TFP change (TFPCH), technology change (TECHCH), efficiency change (EFFCH), has been used in the present study. Researchers have extensively applied this technique for the measurement of TFP growth in the manufacturing industry; therefore, the present study has used this technique to estimate the TFP growth and its components in the Indian garment industry.

The MPI, which is an application of DEA to a panel data to calculate was initially introduced by Caves et al. (1982) and was empirically used by Fare et al. (1992 and1994). In order to avoid choosing the MPI of an arbitrary period Färe et al. (1994) specified the Malmquist productivity change index as:

$$
M_{o}\left(x^{t+1}, y^{t+1}, x^{t}, y^{t}\right)=\sqrt{\frac{D_{o}^{t}\left(x^{t+1}, y^{t+1}\right)}{D_{o}^{t}\left(x^{t}, y^{t}\right)} \frac{D_{o}^{t+1}\left(x^{t+1}, y^{t+1}\right)}{D_{o}^{t+1}\left(x^{t}, y^{t}\right)}}
$$


Färe et al. (1994) further states that the MPI formula in equation (4) can be equivalently rewritten as:

$$
M_{o}\left(x^{t+1}, y^{t+1}, x^{t}, y^{t}\right)=\frac{D_{o}^{t+1}\left(x^{t+1}, y^{t+1}\right)}{D_{o}^{t}\left(x^{t}, y^{t}\right)} \sqrt{\frac{D_{o}^{t}\left(x^{t+1}, y^{t+1}\right)}{D_{o}^{t+1}\left(x^{t+1}, y^{t+1}\right)} \frac{D_{o}^{t}\left(x^{t}, y^{t}\right)}{D_{o}^{t+1}\left(x^{t}, y^{t}\right)}}
$$

The first ratio on the right hand side of equation (5) measures the changes in technical efficiency (EFFCH) between period $t$ and $t+1$ as a catching-up to the frontier effect. The second term measures (TECHCH) the change in production technology (i.e., technical change) usually referred to as a shift in production frontier.

$$
\begin{aligned}
& \text { Technical Efficiency Change }=E C=\frac{D_{o}^{t+1}\left(x^{t+1}, y^{t+1}\right)}{D_{o}^{t}\left(x^{t}, y^{t}\right)} ; \\
& \text { Technological Change }=T C=\sqrt{\frac{D_{o}^{t}\left(x^{t+1}, y^{t+1}\right)}{D_{o}^{t+1}\left(x^{t+1}, y^{t+1}\right)} \frac{D_{o}^{t}\left(x^{t}, y^{t}\right)}{D_{o}^{t+1}\left(x^{t}, y^{t}\right)}}
\end{aligned}
$$

The TFP growth rate can be estimated as:

TFPG $($ Per cent $)=(\text { TFPCH }-1)^{*} 100$

Further, it is to be noted that $M_{o}>1$ reflects a positive TFP growth between two consecutive years. Similarly, improvements in any of the components of $M_{o}$ are also associated with the values greater than unity of these components, and deterioration is associated with the values less than unity. (The terms technological progress, technological change and technical change are used interchangeably throughout the study). Furthermore, even if a sector experiences deterioration in efficiency, it could still end up with a positive growth in TFP if the fall in its efficiency is smaller than the improvement in its technology (Kumar and Arora, 2009).

\section{RESULTS AND DISCUSSIONS}

At the time of independence, Indian economy was predominantly an agricultural economy while the industrial sector was lacking seriously behind. During the first plan period, the contribution of the primary sector in GDP was the largest followed by tertiary and secondary sector. However, economic policy in post independence India was strongly influenced by the ideas that there is high degree of correlation between the extent of industrialization in an economy and its economic development. A natural consequence was that developing countries should embark upon the path 
of industrialization in order to get rid of their economic problems. With the motive to understand the behavior of the economy in question, in terms of growth pattern of GDP, a proxy of overall improvement in the economy and its components, a broader picture has been drawn in the Table 1.

Table 1: Growth Pattern of Macro Indicators of India and Haryana

\begin{tabular}{|l|l|l|}
\hline & India & Haryana \\
\hline Period-I & $5.61^{*}$ & $5.95^{*}$ \\
\hline GDP & $3.13^{*}$ & $3.32^{*}$ \\
\hline Primary Sector & $6.21^{*}$ & $6.21^{*}$ \\
\hline Secondary & $7.10^{*}$ & $8.41^{*}$ \\
\hline Tertiary & $5.40^{*}$ & $6.21^{*}$ \\
\hline Period-II & $3.23^{*}$ & $4.74^{*}$ \\
\hline GDP & $6.73^{*}$ & $7.21^{*}$ \\
\hline Primary Sector & $6.83^{*}$ & $7.74^{*}$ \\
\hline Secondary & \multicolumn{2}{|l|}{} \\
\hline Tertiary & $5.53^{*}$ & $5.53^{*}$ \\
\hline Period-III & $2.71^{*}$ & $2.63^{*}$ \\
\hline GDP & $5.91^{*}$ & $6.93^{*}$ \\
\hline Primary Sector & $7.10^{*}$ & $10.41^{*}$ \\
\hline Secondary & \multicolumn{2}{|l|}{} \\
\hline Tertiary &
\end{tabular}

Source: Authors' Calculations

Note: * Statistically significant at 1 per cent level of significance.

A glance at growth rates of major indicators of Haryana shows that the state has performed well in comparison to All India in all the sectors with growth rates more than national average during the period of 27 years. However, results at disaggregate level shows that GDP of Haryana has improved comparatively in post reforms period from 6.2 per cent in pre reforms period to 6.8 per cent in post reforms period. While tertiary sector has shown improvement in post liberalization era, growth rate of secondary of Haryana dropped off from 7.2 per cent to 6.9 per cent.

The differential growth rates across the sectors have resulted in significant changes in the sectoral composition of GDP. The relative share of the primary, secondary and tertiary sector is plotted for India and as well as for the sample state in Figure 1 and Figure 2, respectively. The general development pattern observed by the Haryana is 
definitely not a healthy sign of structural change in the economy. The analysis of the discussion reflects that while the tertiary sectors have maintained its lion's share in GDP of India and Haryana as well, the declining trend in the share of primary sector growth rates is noticeable during 27 years and this deceleration is not only at national level but also at state level. Whereas the contribution of secondary sector has shown only a marginal rise and it is an alarming situation for the sustainable development of the country.

Table 2: Growth Pattern of Secondary Sector and its Components

\begin{tabular}{|c|c|c|}
\hline & India & Haryana \\
\hline \multicolumn{3}{|l|}{ Period-I } \\
\hline Manufacturing & $6.22^{*}$ & $6.91^{*}$ \\
\hline Construction & $5.71^{*}$ & $3.51^{*}$ \\
\hline Electricity, Gas and Water Supply & $6.82^{*}$ & $8.32^{*}$ \\
\hline \multicolumn{3}{|l|}{ Period-II } \\
\hline Manufacturing & $6.90^{*}$ & $9.31^{*}$ \\
\hline Construction & $4.91^{*}$ & $2.31^{*}$ \\
\hline Electricity, Gas and Water Supply & $9.41^{*}$ & $8.41^{*}$ \\
\hline \multicolumn{3}{|l|}{ Period-III } \\
\hline Manufacturing & $5.61^{*}$ & $7.12^{*}$ \\
\hline Construction & $6.72^{*}$ & $5.18^{*}$ \\
\hline Electricity, Gas and Water Supply & $5.50^{*}$ & $7.40^{*}$ \\
\hline
\end{tabular}

Source: Authors' Calculations

Note: * Statistically significant at 1 per cent level of significance.

Figure 1: Percentage Share of Different Components of GDP of India

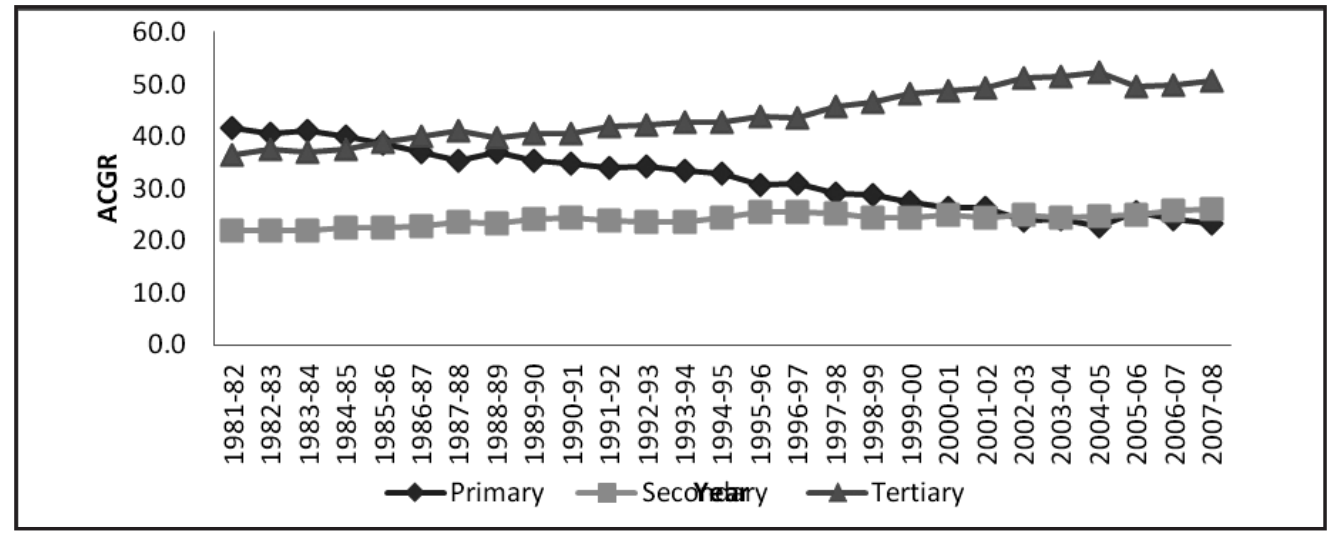

Source: Authors' Calculations. 


\section{Figure 2: Percentage Share of Different Components of GDP of Haryana}

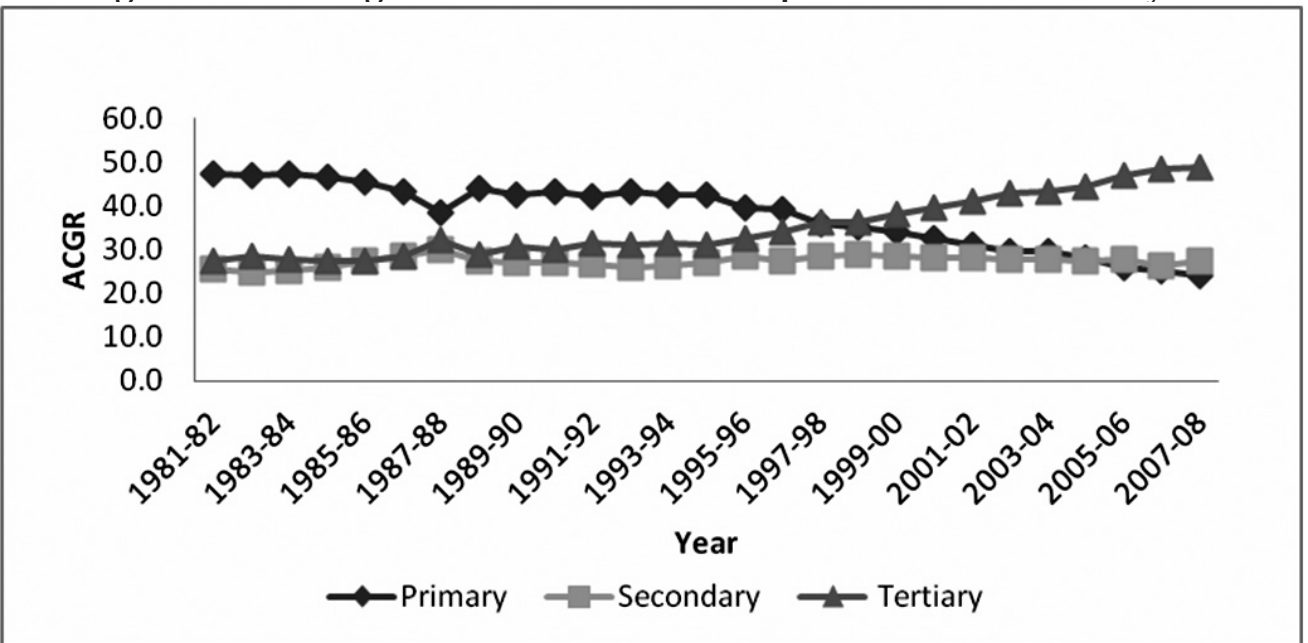

Source: Authors' Calculations.

Industrialization has been viewed as a precondition for economic development. It is not only a generator of economic growth, but also serves as the transformer of the socioeconomic and institutional setup of the economy (Arora and Singh, 2008). The present section attempts to probe into the growth and pattern of intra- sector composition of secondary sector of India and Haryana. One of the important sub-parts of secondary sector is manufacturing sector in any economy. It is widely recognized as a sector which has both the backward and forward linkages with the other sectors of the economy. There is a need to recognize, understand and analyzed its sub-sectors' growth, with its implications for the sustained long term growth and development of the country.

Figure 3: Percentage Share of Different Components of Secondary Sector of India

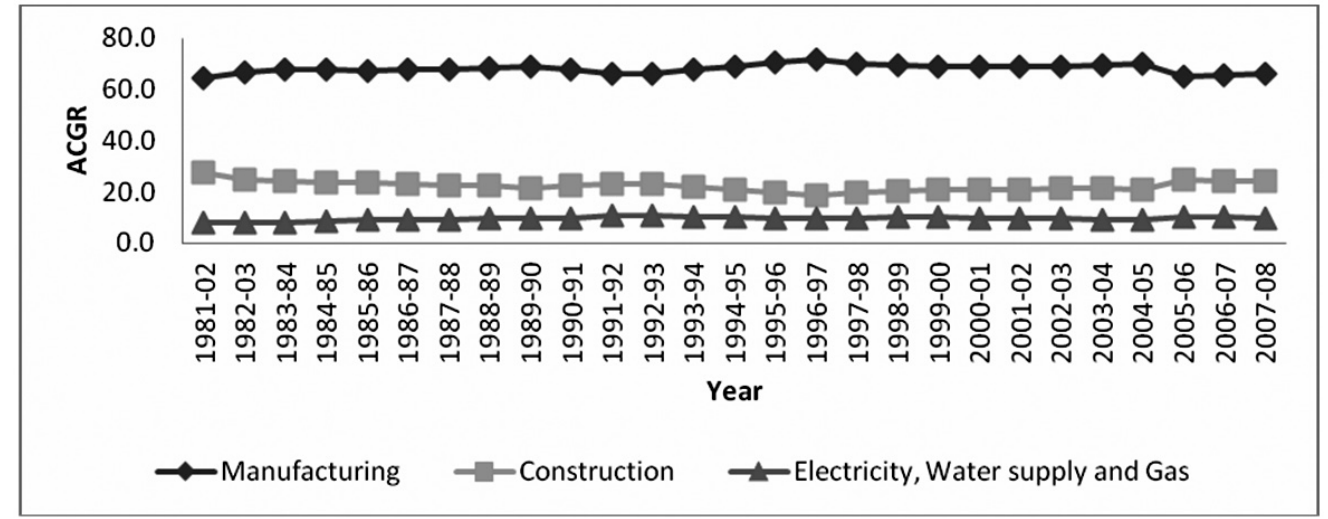

Source: Authors' Calculations. 
A glance at Table 2 indicates that in the state the growth rate of manufacturing sector is more than the national average during pre reforms era but it fall sharply in post reforms period. Also the growth rates of the indicators except construction sector points out that in comparison to All India, Haryana economy is performing well especially for manufacturing sector as the growth rate of the sector is more than growth rate realized at India as a whole. Figure 3 and Figure 4 describes the intra- sector composition of secondary sector in India as well as the state of Haryana, respectively.The time series percentage contribution of different components of secondary sector exhibits that manufacturing has maintained its maximum share in the secondary sector output not only at all India level but also in the state of Haryana.

Figure 4: Percentage Share of Different Components of Secondary Sector of Haryana

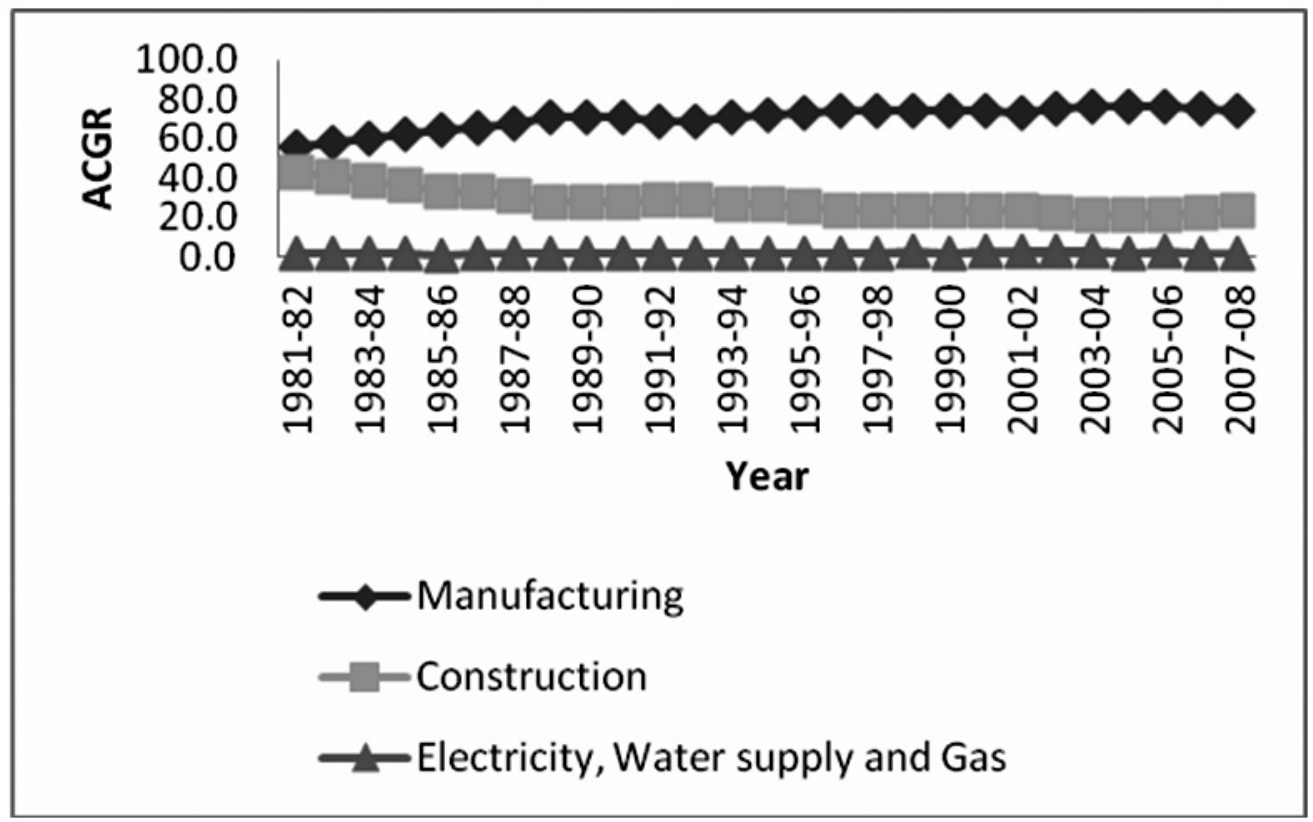

Source: Authors' Calculations

\section{Malmquist Productivity Index (MPI)}

The development of manufacturing industry has been concomitant with the growth, i.e., with spectacular economic progress and rise in level of living (Arora and Singh, 2008). Level of productivity growth considered to be one of the most vital determinants of growth. The understanding of inter-temporal and inter-industry comparison of its growth can guide the policy makers for the formulation of a suitable policy for the proper resource allocation and regional development of the state. Inter-temporal and inter-industry comparison of Malmquist Productivity Index is provided by the 
Figure 5 and Figure 7. Inter-temporal analysis reveals a cyclical fluctuation in the productivity growth rates for the manufacturing sector of Haryana. During 1982-83 a lowest growth rate of TFP has been observed in comparison to the highest TFP growth of it during the year 1990-91. During the majority of the years the MPI is less than unitary and explaining the level of productivity for manufacturing sector, which is not very encouraging one. During the post reforms era the growth pattern of MPI reflects relatively better picture. Besides, having a glimpse at the Table 3, it is observed that there is productivity regress in the manufacturing sector of Haryana at the rate of -1.455 per cent per annum. The growth rate ranges between maximum of 3.65 per cent per annum for the Group Xi.e. Manufacture of transport and with a minimum for the Group III i.e. Manufacture of wood (-6.002 per cent).

Figure 5: Average of TFPCH, EFFCH and TECHCH: An Intertemporal Analysis

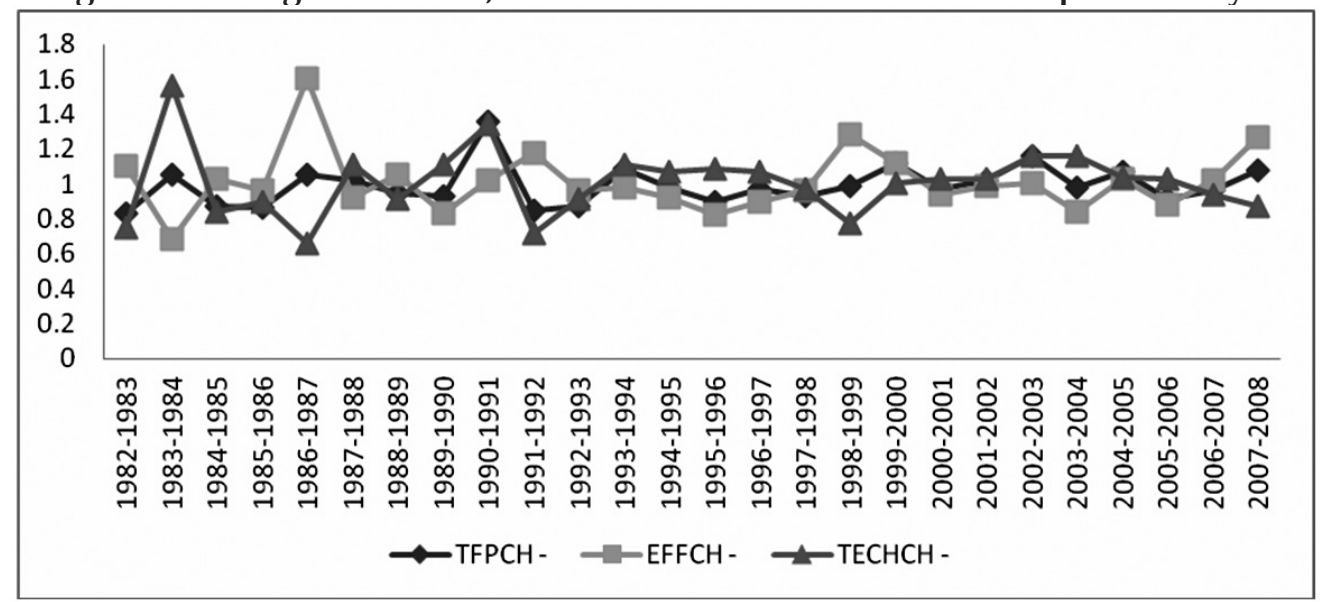

Source: Authors' Calculations

Thus, there exists a huge variation in productivity growth of manufacturing sector of Haryana. Further, the industry groups of Manufacture of transport and Manufacture of other manufacturer are the only groups demonstrating a positive growth during period-I. In case of Group I and III the results are really disquieting as the state's economy significantly contributed by the agriculture sector. For food and beverage based organized manufacturing sector the results of the growth rates are more bothersome during the period-III. While analyzing the results, it is revealed an improvement in TFPG given that the productivity growth has improved from -3.233 per cent per annum during period-II to -0.32 per cent during period-III. Although the second sub-period is also reporting productivity regress, nonetheless the rate of productivity regress has been held up during the post reforms period. 
Figure 6: Growth Rate of TFPCH, EFFCH and TECHCH: An Intertemporal Analysis

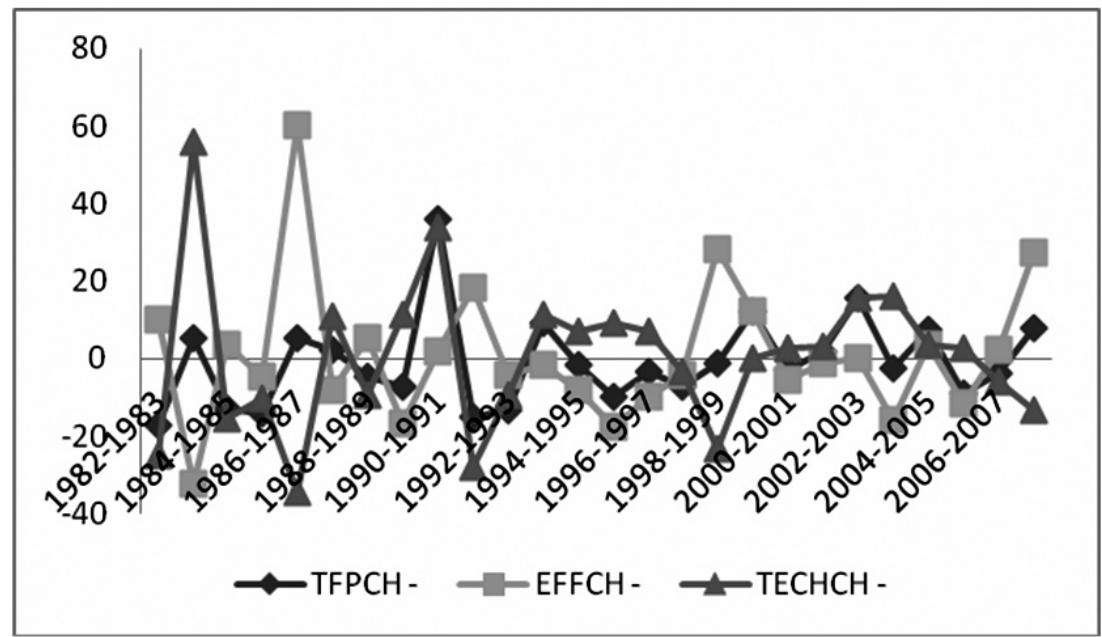

Source: Authors' Calculations

Almost all the industrial groups have improved their TFP during the post reforms period except for Group I, V and XI, where the growth rates replicates fall in TFPG. However, it is relevant to point out here that during post reforms period the industrial groups of Manufacture of transport, Manufacture of other manufacturing, Manufacture of cotton and textile, Manufacture of paper and Manufacture of basic chemical have exhibited a positive productivity growth. Additionally, to be more precise, in the state the Group, X, VI, and, XI in decreasing order, can be classified as the star performer on the basis of MPI growth rates for the period under study.

Figure 7: Malmquist Productivity Index for the State of Haryana: An Inter- Industry Analysis

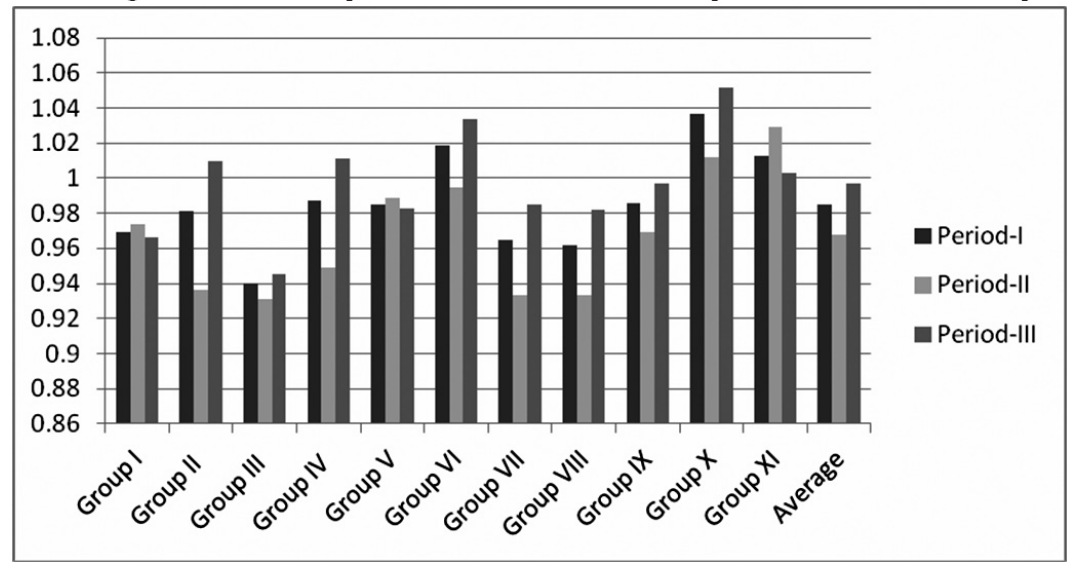

Source: Authors' Calculations 
Note: Group I: Manufacture of Food and Beverages; Group II: Manufacture of Cotton and Textile; Group III: Manufacture of Wood; Group IV: Manufacture of Paper; Group V : Manufacture of Leather; Group VI: Manufacture of Basic Chemical; Group VII: Manufacture of Rubber; Group VIII: Manufacture of Non Metallic and Basic Alloy; Group IX: Manufacture of Machinery and Machine Tools; Group X: Manufacture of Transport ; Group XI: Manufacture of Other Manufacturing Industries.

\section{Decomposition of MPI}

According to MPI approach, TFP can increase not only due to technical progress i.e. shifting of production frontier but it is also due to the improvement in TE i.e. catching-up. MPI allows to distinguish between shifts in the frontier i.e. TECHCH, and improvements in efficiency relative to the frontier, that is, $\mathrm{EFFCH}$, which are two mutually exclusive and exhaustive sources of TFP change. Figure 5 and Figure 6, respectively provide the inter-temporal estimates of efficiency change and technological progress.

A broader visualization of the Figure 4 explains that technical efficiency change index is less than unitary for majority of the years considered under study. The behaviour of the coefficients of growth rates summarizes a mix of positive and negative values. The highest growth of 60.39 per cent is experienced during the year 1986-87; however during the period-III the same was 28.38 per cent (1998-99). During the last year of the study (2007-08) growth rate was 27.39 per cent thus trend ends with an optimistic note for the technical efficiency change. On the other hand, the growth rate of technological change is found to be optimum during the year 1983-84(55.66 per cent), while for the post reforms era it was maximum during the year 2003-04(16.28 per cent).

Figure 8: Technical Efficiency Index for the State of Haryana: An Inter- Industry Analysis

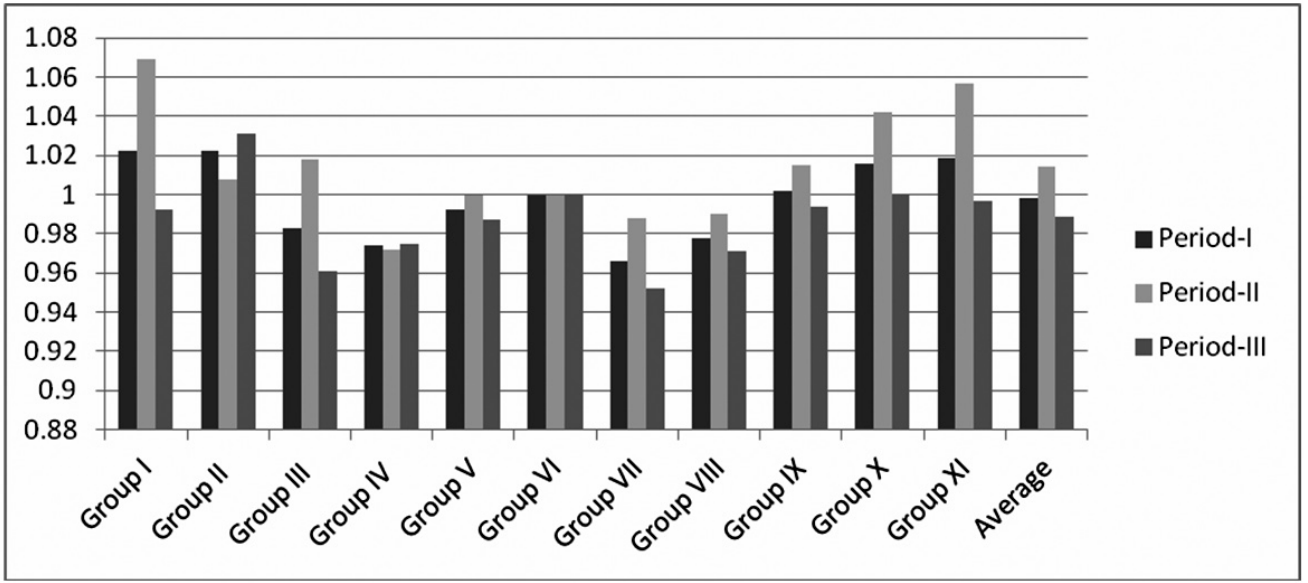

Source: Authors' Calculations 
An inter industry analysis of EFFCH for the manufacturing sector of Haryana is explained by the Figure 8. A comparative analysis of pre and post reforms period suggests that industrial groups of Manufacture of cotton and textile have experienced improvement in technical efficiency from 0.804 per cent in pre reforms to 3.108 per cent during post reforms period. During the same time, Manufacture of food and beverage, Manufacture of wood, Manufacture of machinery and machine tools, Manufacture of transport, Manufacture of other manufacturing industries have experienced a decline in EFFCH.

Figure 9: Technological Change Index for the State of Haryana: An Inter- Industry Analysis

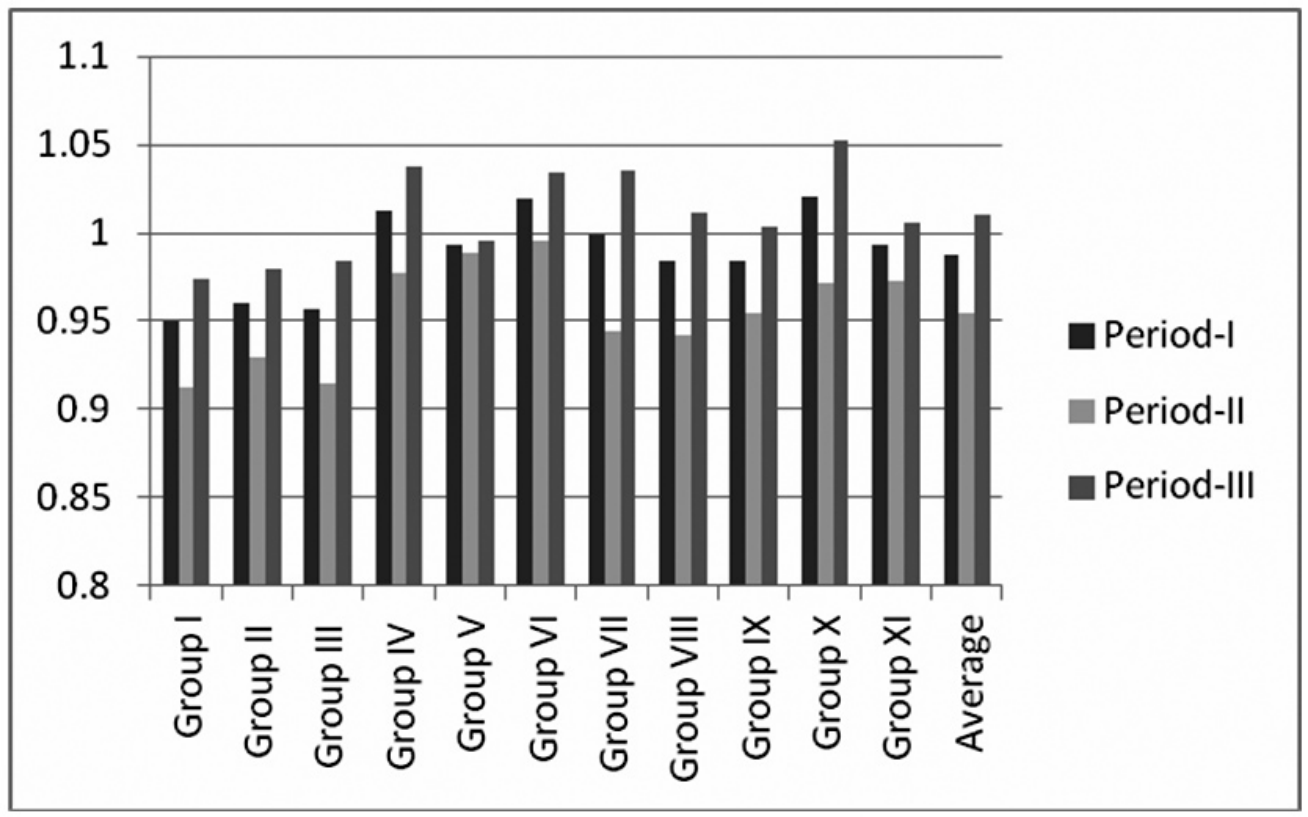

Source: Authors' Calculations

Table 3 provides a detail of growth rate of TEPCH, EFFCH and TECHCH enjoyed by different groups of manufacturing industries in the state of Haryana. 
Table 3 : Growth Rate of TFPCH, EFFCH and TECHCH: An Inter-Industry Analysis

\begin{tabular}{|l|c|c|c|c|c|c|c|c|c|}
\hline & \multicolumn{2}{|c|}{ TFPCH Growth Rate } & \multicolumn{2}{c|}{ EFFCH Growth Rate } & \multicolumn{3}{c|}{ TECHCH Growth Rate } \\
\hline $\begin{array}{l}\text { Manufacturing } \\
\text { Groups }\end{array}$ & $\begin{array}{c}\text { Period- } \\
\text { I }\end{array}$ & $\begin{array}{c}\text { Period- } \\
\text { II }\end{array}$ & $\begin{array}{c}\text { Period- } \\
\text { III }\end{array}$ & $\begin{array}{c}\text { Period- } \\
\text { I }\end{array}$ & $\begin{array}{c}\text { Period- } \\
\text { II }\end{array}$ & $\begin{array}{c}\text { Period- } \\
\text { III }\end{array}$ & $\begin{array}{c}\text { Period- } \\
\text { I }\end{array}$ & $\begin{array}{c}\text { Period- } \\
\text { II }\end{array}$ & $\begin{array}{c}\text { Period- } \\
\text { III }\end{array}$ \\
\hline Group I & -3.05 & -2.552 & -3.361 & 2.207 & 6.885 & -0.798 & -5.045 & -8.784 & -2.631 \\
\hline Group II & -1.881 & -6.375 & 1.037 & 2.216 & 0.804 & 3.108 & -4.015 & -7.127 & -2.017 \\
\hline Group III & -6.002 & -6.864 & -5.458 & -1.728 & 1.828 & -3.888 & -4.341 & -8.5 & -1.645 \\
\hline Group IV & -1.332 & -5.137 & 1.124 & -2.622 & -2.843 & -2.484 & 1.338 & -2.33 & 3.701 \\
\hline Group V & -1.487 & -1.148 & -1.699 & -0.824 & -0.049 & -1.305 & -0.683 & -1.126 & -0.405 \\
\hline Group VI & 1.872 & -0.458 & 3.356 & -0.003 & -0.005 & -0.001 & 1.87 & -0.458 & 3.354 \\
\hline Group VII & -3.506 & -6.694 & -1.459 & -3.406 & -1.159 & -4.784 & -0.101 & -5.603 & 3.499 \\
\hline Group VIII & -3.758 & -6.741 & -1.845 & -2.162 & -0.98 & -2.894 & -1.627 & -5.805 & 1.078 \\
\hline Group IX & -1.373 & -3.051 & -0.309 & 0.221 & 1.504 & -0.572 & -1.588 & -4.499 & 0.276 \\
\hline Group X & 3.654 & 1.207 & 5.214 & 1.595 & 4.189 & 0.006 & 2.035 & -2.86 & 5.22 \\
\hline Group XI & 1.253 & 2.868 & 0.256 & 1.923 & 5.656 & -0.343 & -0.661 & -2.656 & 0.606 \\
\hline Average & -1.455 & -3.233 & -0.327 & -0.177 & 1.399 & -1.15 & -1.193 & -4.562 & 0.972 \\
\hline & & & & & & & & & \\
\hline
\end{tabular}

Source: Authors' Calculations

The analysis shows that out of 11, 3 groups, that is, Manufacture of Paper, Manufacture of basic chemical and Manufacture of transport have experienced technological progress during the period-I (refer Figure 9). A probe for examining the impact of economic reforms highlights that strong positive technical change is observed for all the industries of Haryana barring Groups I, II, III, and V. The Manufacture of basic chemical has remained the most efficient during the study period. Hence, suggesting a positive impact of liberalization policy on technological advancement.

With the intention to prepare a comparative picture of the two indicators, it has been observed that for aggregate period of 27 years technological regress at the rate of -1.193 per cent as the major source of productivity regress whereas efficiency regress is observed to be insignificant and scant source of TFPG, however, a comparative analysis of decomposition over the two sub periods reveals that an improvement in TECHCH during the post reforms period is responsible for the observed productivity growth improvement in the manufacturing sector of Haryana. The impact of economic reforms on efficiency change has been observed to be lackluster. Haryana is a capital 'poor', energy 'deficient' state (Sharma, 2011) presence of inefficiency in the utilization of these scarce resources needs urgent attention. The rate of growth of efficiency has decelerated from 1.39 per cent (refer Table 3) per annum in the pre reforms period to 
1.15 per cent per annum during the post reforms period. During the second sub period the negative efficiency change at the rate of 1.15 per annum over weighs the rate of technological change and therefore, provides a negative productivity growth for the manufacturing sector of Haryana. Arora and Singh (2008) have also experienced results on the similar lines for the state of Haryana for the aggregate manufacturing sector.

\section{Sources of Productivity}

Policy actions intended to improve the TFPG might be badly misdirected if the policy makers focused on accelerating the rate of innovation in circumstances where the cause of lagging the growth is low rate of mastery or diffusion of best practise technology (Nishimizu \& Page, 1982 as cited in Kumar \& Basu, 2008). Therefore, it is quite essential to know the sources of TFPG for a better policy framework. The analysis confirms that at aggregate level the major source of the level of TFPG for the manufacturing sector of Haryana is the technical efficiency for the period-I as described by the Table 4. Among the industrial groups, it is the industrial group of Manufacture of paper, Manufacture of leather, Manufacture of basic chemical, Manufacture of rubber, Manufacture of transport and Manufacture of non metallic and basic alloy, where technological advancement dominates the efficiency change and therefore observed to be the major drivers of productivity improvement of these industries. However, in rest of the industries efficiency change is greater than technical progress. A comparison of pre and post reforms suggests that during the post reforms era except for industrial group Manufacture of food and beverage and Manufacture of cotton and textile, TECHCH is greater than $\mathrm{EFFCH}$ in all the other industrial groups and for the entire manufacturing sector as well, which implies that growth in TFP was due to innovation rather than improvement in efficiency.

\section{Innovations in Manufacturing Sector of Haryana}

Although it has been observed that technical efficiency change is the dominant source in the manufacturing sector of Haryana for the entire study period, yet it becomes pertinent to identify for different years the manufacturing sector categories which are the best practisers as well as the innovators. An innovator industrial group is that who has been observed technically efficient in a given year and also shift its frontier outward in the succeeding year i.e. if the following three conditions are satisfied than the industrial group is known to be an innovator (Fare et.al., 1994). The three conditions are (Kumar \& Managi, 2009):

(a) $\mathrm{TECH}_{\mathrm{t}}^{\mathrm{t}+1}>1$;

(b) $\mathrm{D}_{\mathrm{i}}^{\mathrm{t}}\left(\mathrm{x}^{\mathrm{t}+1,} \mathrm{y}^{\mathrm{t}+1}\right)>1 ;(\mathrm{c}) \mathrm{D}_{\mathrm{i}}^{\mathrm{t}+1}\left(\mathrm{x}^{\mathrm{t}+1}, \mathrm{y}^{\mathrm{t}+1}\right)=1$

Analysis of Innovations discloses that over the period of time almost all the industries have remained innovative. The period-II frequency count (16) is almost equal to period- 
III frequency count (17). Thus, the liberalization process also seems to be positively affecting the research and development in the manufacturing sector of Haryana. For the industrial groups of Manufacture of food and beverage, Manufacture of leather, Manufacture of machinery and machine tools, Manufacture of transport and Manufacture of other manufacturing industries, frequency count of innovations have increased during period-III in comparison to period-II (refer Table 4). On the other side, for industrial groups of Manufacture of cotton and textile and Manufacture of basic alloy and non metallic, no innovation is observed during the pre or post reforms period implying that innovation process has not started in these industries. The results also depict that Group VI i.e. Manufacture of machinery and machine is the most innovating industrial group narrowly chased by Manufacture of basic chemical, Manufacture of wood and Manufacture of leather.

Table 4: Vital Indicators of Productivity Behaviour for the Manufacturing Sector of Haryana

\begin{tabular}{|c|c|c|c|c|c|c|}
\hline \multirow{3}{*}{$\begin{array}{c}\text { Manufacturing } \\
\text { Groups }\end{array}$} & \multicolumn{3}{|c|}{ Sources of TFPG } & \multicolumn{3}{c|}{ Analysis of Innovations } \\
\cline { 2 - 7 } & \multicolumn{2}{|c|}{ TECHCH > EFFCH } & \multicolumn{2}{c|}{$\begin{array}{c}\text { Inter-Temporal and Inter-Industry } \\
\text { Analysis of Innovations }\end{array}$} \\
\cline { 2 - 7 } & Period- I & Period-II & Period-III & Period-I & Period-II & Period-III \\
\hline Group I & N & N & N & 2 & 0 & 2 \\
\hline Group II & N & N & N & 0 & 0 & 0 \\
\hline Group III & N & Y & Y & 5 & 5 & 0 \\
\hline Group IV & Y & Y & Y & 1 & 1 & 0 \\
\hline Group V & Y & N & Y & 5 & 2 & 3 \\
\hline Group VI & Y & N & Y & 6 & 5 & 1 \\
\hline Group VII & Y & N & Y & 1 & 1 & 0 \\
\hline Group VIII & Y & N & Y & 0 & 0 & 0 \\
\hline Group IX & N & N & Y & 9 & 9 & 7 \\
\hline Group X & Y & N & Y & 1 & 1 & 1 \\
\hline Group XI & N & N & Y & 3 & 3 & 3 \\
\hline Aggregate & N & N & Y & 33 & 16 & 17 \\
\hline
\end{tabular}

Source: Authors' Calculations

Note: Y-Yes and N-No 


\section{CONCLUSION AND SUGGESTIONS}

The present analysis of TFP measurement in manufacturing sector of sample state of Haryana is confined to the period from 1981-82 to 2007-08. The required two digit level data of manufacturing sector of Haryana in a balanced panel data format for different types of 11 industry groups of manufacturing industries establishes that overall the state of Haryana is facing productivity regress. Moreover, the post reforms period is also reporting productivity regress, yet the rate has been slowed down during the period. Decomposition of MPI into TECHCH and EFFCH reveals that technical efficiency change is the key driver of TFPG in the manufacturing sector of Haryana during pre reforms period, however, the picture has turned around during the post reforms period. In some of the agro based industries like food and cotton and textile based manufacturing industries, the major driver of increase in productivity is efficiency rather than technical progress during the post reforms period. Technological change is found to be greater than efficiency change in all the other industrial groups and for the entire manufacturing sector as well, which implies that growth in TFP was due to shift in the frontier rather than improvement in efficiency in Haryana during the post reforms period. Hence, suggesting a positive impact of liberalization policy on technological advancement of the manufacturing sector of the state. Thus, during the post reforms period the state has realized inefficiency in the utilization of resources in hand and it is really an alarming sign indicating that the incapability of manufacturing sector of the state in question to cope up with the technological advancement.

The outcomes also depicts that industrial group manufacture of machinery and machine is the most innovating industrial group intently trailed by Manufacture of basic chemical, Manufacture of wood and Manufacture of leather. As against this, for industrial groups of Manufacture of cotton and textile and Manufacture of basic alloy and non metallic, there is complete absence of innovative experience which reveals a threat of survival in the long run for these types of manufacturing industries. The Manufacturer of food and beverages, Manufacturer of wood, Manufacturer of leather, Manufacturer of rubber, etc. chiefly during the post reforms period have performed poorly on productivity growth frontage and these categories of industries are facing hindrance on both the aspects of technological change as well as technical efficiency. There is urgent need to take critical scrutiny and cognizance for revitalization of emerging tendency among these categories of manufacturing sector of the Haryana. The communiqué is strident and lucid that for the state of Haryana, with the purpose to enhance the manufacturing sector of the economy, there is urgent need to ascertain not only strengthening the level of innovations and optimum utilization of resources but also critical responsibility to balance and harmonize both the above mentioned aspects. This will help to utilize the scarce inputs like capital and lends a hand to walk on the itinerary of rapid development of manufacturing sector and economy at large. 


\section{References}

Ahulwalia, I.J. (1991). Productivity and growth in Indian manufacturing. Delhi: Oxford University Press.

Arora, V. \& Singh, P. (2008). Economic reforms and productivity growth in Indian manufacturing sector: An interstate analysis. The Icfai University Journal of Industrial Economics, 5(3), 35-47.

Balakrishnan, P. \& Pushpangadan, K. (1994).Total factor productivity growth in manufacturing industry: A fresh look. Economic and Political Weekly, 29, 20282035.

Caves, D.W., Christensen, L. R. \& Diewert, W. E.(1982).The economic theory of index numbers and the measurement of input, output and productivity. Econometrica, $50,1393-1414$.

Fare, R., Grosskopf, S., Norris, M \& Zhang. Z. (1994). Productivity growth, technical progress and efficiency changes in industrialized countries. American Economic Review, 84, 66-83.

Färe, R. \& Grosskopf, S. (1992). Malmquist indexes and fisher ideal indexes. The Economic Journal, 102(410), 158-160.

Goldar, B. (1986). Productivity growth in Indian industry. New Delhi: Allied Publishers.

Goldar, B. \& Veeramani, C. (2005). Manufacturing productivity in Indian states: Does investment climate matter? Economic and Political Weekly, 40, 2413-2420.

Grifell-Tatjé, E., \& Lovell, C.A.K. (1995). A note on the Malmquist productivity index. Economics Letters, 47(2), 169-175.

Jayadevan, C.M. (1995). Inter-state variations in employment growth rates: Evidence from organized industry in India. Indian Journal of Regional Science, 27(1-2), 41-56.

Joshi, R.N. \& Singh, S.P. (2010). Estimation of total factor productivity in the Indian garment industry. Journal of Fashion Marketing and Management, 14(1), 145-160.

Krugman, P. (1990). Increasing Returns and Economic Geography. NBER Working Papers No. 3275.

Krugman, P. (1994). The myth of Asia's miracle. Foreign Affairs, 73, 62-78.

Kumar, M. \& Basu, P. (2008). Perspectives of productivity growth in Indian food industry: a data envelope analysis. International Journal of Productivity and Performance Management, 57, 503-522.

Kumar, S. (2006). A decomposition of total factor productivity growth: A regional analysis of Indian industrial manufacturing growth. Working Paper No. 22, NIPFP, New Delhi. 
Kumar, S. \& Managi, S. (2009). Productivity and convergence in India: State level analysis. MPRA Paper No. 23738, (Available at http:// mpra.ub.unimuenchen,de) 23738/

Kumar, S. \& Arora, N. (2009).Does inspiration or perspiration drive the output growth in manufacturing sector? -- An experience of Indian states. Indian Journal of Economics, 89, 569-598.

Kumar, S. (2004). Decomposition of total factor productivity growth: A regional analysis of Indian ind ustrial manufacturing growth. Working Papers 04/22, National Institute of Public Finance and Policy.

Kuznets, S. (1965). Economic growth and structure: selected essays. New York: W. W. Norton and Company Inc.

Mahadevan, R. (2002). A DEA approach to understanding the productivity growth of Malaysia's manufacturing industries. Asia Pacific Journal of Management, 19, 587-600.

Manjappa, D.H. \& Mahesha, M. (2008). Measurement of productivity growth, efficiency change and technical progress of selected capital-intensive and labour-intensive industries during reform period in India. Indian Journal of Economics and Business, 5 (4), 57-65.

Misra, A. (2006). Growth and structural change in manufacturing industries since 1980-81 to 2001-2002. The Journal of SRMCEM, 1, 71-76.

Ray, S.C. \& Desli, E. (1997). Productivity growth, technical progress and efficiency change in industrialized countries: comment. American Economic Review, 87, 1033-1039.

Ray, S. C. (1997). Regional variation in productivity growth in Indian manufacturing: A nonparametric analysis. Journal of Quantitative Economics, 13, 73-94.

Ray, S. C. (2002). Did India's economic reforms improve efficiency and productivity? A nonparametric analysis of the initial evidence from manufacturing. Indian Economic Review, 37, 23-57

Sharma, H. (2011). Factor substitution and price elasticity of demand in Haryana manufactur ing industries. The IUP Journal of Applied Economics, 10 (2), 74-89.

Shephard, R. W. (1970).Theory of cost and production functions. Princeton: Princeton University Press.

Trivedi, P. (2004). An inter-state perspective on manufacturing productivity in India: 1980-81 to 2000-01. Indian Economic Review, 39(1), 203-237.

Unel, B. (2003). Productivity trends in India's manufacturing sectors in the last two decades. Working Paper No.03/22, IMF, Washington

Young, A. (1992) .The tyranny of numbers: confronting the statistical realities of the East Asian growth experience. Quarterly Journal of Economics, 110, 641-80. 